\title{
Social Media Network—A Seminal Paradigm for Interactive Marketing
}

\author{
Kumarashvari Subramaniam \\ Multimedia University, Cyberjaya, Malaysia \\ T.R. Gopalakrishnan Nair \\ Prince Mohammad bin Fahd University, Al Khobar, Saudi Arabia
}

\begin{abstract}
In the era of globalization, effective communication between the enterprises and the target audience is a crucial issue in achieving strategic targets in business. However, with the advancement in the technology, especially the introduction of Internet in the 20th century, marketing communication channels are subjected to a quiet transition incorporating the facilities of the social media networking. This paper discusses the transition scenario of marketing communication channels from traditional architectures to social media networking. It is an undeniable fact that the traditional channels like newspaper, billboards, radio, etc. are still in vogue. However, the presences of the social media networking started influencing the way enterprises communicate with their target audience. It has become quite evident now that more individuals and enterprises are engaged in communication using the social media networking sites for business transactions. At the same time, large number of end users makes use of social media networking in reading "reviews" and the post-purchase feedback notes. The changing scenario in this domain of marketing communication has influenced this research and it involved a study spanning one year (September 2011-October 2012). This paper also intends to highlight the uniqueness of the social media networking. It also depicts how the user oriented applications manage and influence the purchase decisions of the audience. The statistical analysis is carried out to study the influential properties of social media networking and it involves the quantitative analysis of the user preferences. The samples organized for this study portrays the involvement of enterprises in the utilization of social media networking. It can be concluded that the existence of social media networking not only augments to social interaction but also extends the experience of having a desirable shopping experiences for the consumers. It also offers the enterprises an opportunity to interact with their target audiences resulting in the transfer of marketing messages.
\end{abstract}

Keywords: traditional marketing communication, social media networking, virtual shopping

\section{Introduction}

One of the major concepts of modern marketing is to rely on an appropriate mix of business aspects like commodities, cost, convenience, and communication. The marketing mix consists of everything that the firms can plan and implement in order to create a demand for its product. Enterprises commonly identify themselves

Kumarashvari Subramaniam, Institute of Postgraduate Studies, Faculty of Management, Cyberjaya, Malaysia.

T.R. Gopalakrishnan Nair, Aramco Endowed Chair, Prince Mohammad bin Fahd University.

Correspondence concerning this article should be addressed to Kumarashvari Subramaniam, Female Campus, College of Business, Prince Mohammad bin Fahd University, PB 1664, 31952, Al Khobar, Saudi Arabia. E-mail: eiswary@hotmail.com. 
as sellers of products and customers distinguish themselves as the buyers of these products or solutions.

The current trend in the world indicates that a normal customer is no more bound to a "just" price of the product but he/she is driven by intriguing desires of utility and a pertinent attitude to know about the total cost of ownership of the product. This is a change in the consumer awareness which is continually fueled by the advancement of information technology and as such the social media networking. The world is moving more and more towards internet bound, the desire for awareness is directly or indirectly controlled by scenarios mainly created by Internet based interactions.

Usually it is of two types: the first one belongs to the unidirectional read enabled interactions; whereas the second type belongs to the bi-directional expression and exchanges of opinions and viewpoints. The enterprises are now targeting a large population who are interacting with the internet under these two modes of operations.

Therefore, the study of the communication or promotion field demands more focus, as it is a vital agenda for enterprises. Conventionally, the field of Integrated Marketing Communication (IMC) consists of several approaches such as sales promotion, trade fairs, public relations, bill board, and printed media. However, in the 21st century, the field of IMC can be categorized into several segments as follows.

\section{Personal Communication}

This form of transaction refers to communications by an enterprise with a target audience either through message delivered by a sales person in a face to face way or by a person to an audience through the media like telephone, email, couriers, and smart phones or through a chatting using web-cam. Enterprises take various steps to stimulate personal communication for their offerings and brands in the segmented market across the globe.

\section{Hybrid Communication}

This form of transaction refers to the usage of traditional and conventional marketing communication platform for the purpose of "reaching out" to a target audience and to persuade the target audiences to involve in a purchase decision. These forms of communication include printed media (magazines, billboards, newspapers), electronic media (CD-ROM, electronic email, short messaging systems), and enterprises arranged events such as exhibitions, sponsorship, trade fairs etc.

\section{Social Media Networking (SMN)}

SMN is a web-based application that allows anyone to construct any web contents, from uploading photos, videos to descriptions like personal, organizational, or employers' details. More interestingly it can publicly display a list of other users with whom they can share connection (Boyd \& Ellison, 2007). In the recent years, SMN has evolved in a fast pace as a media to create communication between individual to individual or enterprises to an individual. The Internet has enabled SMN sites to grow in a fast pace and it is becoming as one of the most rapidly influencing platform in the history of information technology.

\section{Research Background}

The SMN application allows individuals to share information and communicate on the network regardless of time or geographical restriction. According to Kaplan and Haenlein (2010), social media as an Internet based applications, allows people of all age regardless of geographical area or time to actively share their information. Additionally, research by Cann, Dimitriou, and Hooleyl (2011), claims that social media is a suitable internet based application, that allow users to generate contents too. 
The internet has revolutionized the information technology world to an extraordinary level. A study by Ria novosti Internet User Report (2012), indicates there are about two billion internet users worldwide in the year 2011 and about 45\% of the Internet users live in Asia. China seems to be leading with about 485 millions of internet users. It is evident that the Social Media (SM) network is growing in a fast pace and is becoming one of the most rapidly growing media or mode in the history of Internet. The Internet has transformed the information technology world to a level having a multiplying effect on competence. The number of internet users will continue to escalate and it is projected to reach 2.8 billion users worldwide soon (Melanson, 2011).

The SMN sites such as FaceBook ${ }^{\circledR}$, My Space ${ }^{\circledR}$, Second Life ${ }^{\circledR}$ all allow individuals of all age to share their information and daily activities (Hove, 2010). The escalating number to SMN sites has changed the way individuals and enterprises interact within a commercial perspective (N. D. Barnes \& F. R. Barnes, 2009). Therefore, the evolutions of SMN sites and on the other hand the involvement of consumers with them are escalating rapidly. Table 1 indicates different SMN sites in use with number of users and nations that actively get involved with this application.

Table 1

Social Media Networking Sites With Heavily Involved Region-2012 Statistics

\begin{tabular}{lcl}
\hline Sites & World users (million) & Heavily involved region \\
\hline FaceBook ${ }^{\circledR}$ & 850 & Tunisia \\
Twitter ${ }^{\circledR}$ & 465 & Brazil \\
Friendster ${ }^{\circledR}$ & 100 & Philippines \\
Mixi ${ }^{\circledR}$ & 23 & Japan \\
Flickr ${ }^{\circledR}$ & 50 & United Kingdom \\
My Space ${ }^{\circledR}$ & 63 & United States \\
Ren Ren ${ }^{\circledR}$ & 130 & China \\
Orkut ${ }^{\circledR}$ & 65 & India \\
\hline
\end{tabular}

During the ending period of 20th century, the Internet was perceived as a "perfect virtual notice board" but in the recent years, since 2007 or 2008 it has gone a step ahead with the evolution of SMN sites. Even though, during the year 2010, many SMN sites were closed their operations, such as Team Sugar and Propeller, this phenomena did not affect brands such as Facebook ${ }^{\circledR}$ and Twitter ${ }^{\circledR}$. Additionally, RenRen ${ }^{\circledR}$ has become the key social network giant in China and Orkut ${ }^{\circledR}$ in India for some time. Other sites like Friendster ${ }^{\circledR}$ have a great diffusion in the Philippines, and Mixi ${ }^{\circledR}$ has become one of the most popular sites in Japan. The same is the case with MySpace ${ }^{\circledR}$ in the USA and it seems to lead the scenario regionally.

Facebook ${ }^{\circledR}$ has the highest number of users, reaching 850 million users in 2012. The other SMN sites that sharing the pie with Facebook ${ }^{\circledR}$ are Orkut ${ }^{\circledR}$, Linked In ${ }^{\circledR}$, Mixi ${ }^{\circledR}$, Pinterest ${ }^{\circledR}$ etc. The SMN channels were well received by individuals and it has clearly positioned in the mind set of a large population. Its unique properties such as enabling users to access the channel from anywhere on the globe and to track information from different platforms have lead to the success of SMN. SMN sites allow individuals to gather information and search for post purchase feedback, virtually in a very comfortable pace, according to Safko and Brake (2009).

It is also an unquestionable fact that the advancement in the digital technology has enable enterprises and individuals to communicate with millions of people through the SMN sites (Mangold \& Faulds, 2009). There is a pervading transition taking place in marketing communication and it happens through the invisible medium enveloping the mind of people, across the globe through the power of social media networks. 
A study by Nair and Subramaniam (2012) claimed that evolution of individual's consumerism through the SMN has caused pressure for extensive migration by business organization towards SMN sites. On the other hand, the Zenithoptimedia report (2012) predicts that the global advertising expenditure in these channels will reach US\$464 billion soon, 3.5\% higher than in 2010, and then should accelerate to around US\$486 billion, a 4.7\% growth despite the economic recession in Europe and debt crisis prevailing in many regions. In this segment, internet alone grows from US\$73 billion to US\$84 billion. The study clearly indicates the increased spending attitude of enterprises to the virtual world for realizing effective communication.

\section{Uniqueness and Accessibility}

The usage of SMN channel continues to grow briskly, as it provides a conduit to connect, share, shop and network among people. Additionally, increase in the number of mobile phone usage has lead to an increase in the access rate of SMN sites. According to the New Media Trend Watch (2012) nearly two in five social media users' access to the SMN sites from their mobile phones.

It is reported that mobile phones subscription has escalated to five billion in number. It is absolutely undeniable that under the Traditional Marketing Communication (TMC), an individual has only limited ways to learn about a product like printed media, television or billboards.

However, now with the advancement available in the information technology, the knowledge about a product can be learned in numerous ways such as SMN and multimedia sites. As a result of various innovations, the SMN sites can be accessed through personal computer, laptop, iPhone, tablet or any other ordinary cell phone that has an internet connection. Table 2 indicates a number of access channels to the SMN sites that is used by individuals.

Table 2

Access Channel to the Social Media Networking Sites

\begin{tabular}{llll}
\hline Item & Access channels & Score (\%) & Ranking \\
\hline 1 & Computer & 97 & 1 \\
2 & E-reader & 2 & 5 \\
3 & Gaming Console & 3 & 3 \\
4 & Handhold Media Player & 1 & 7 \\
5 & Internet Enable TV & 2 & 5 \\
6 & iPad & 3 & 3 \\
7 & Mobile Phone & 37 & 2 \\
\hline
\end{tabular}

Its unique characteristics give individuals an easy access and interactive options to a large population regardless of location and time. In line with it, enterprises are embracing SMN in order to closely and directly interact with their target audience. Additionally, offering a potential and valuable advertising platform for enterprises. It is also noted that about $84 \%$ of Fortune 100 companies and about $81 \%$ of the top Asian companies are using branded social media channels for the purpose of reaching out its target audience, according to the Burson-Marsteller Asia Pacific (2011).

It is clear that SMN sites continue to play an important part in the marketing communication field. Even though at some point SMN sites may reach the saturation point, but it does not look like that point will arrive any time soon. According to Arno (2012), there will be 1.43 billion SMN account users in the year 2012, which represent 19.2\% increase over 2011 figures.

Additionally to the Booz \& Company and Buddy Media (2011) reported that a survey result indicates that 96\% 
of companies would be increasing their investments into the SMN sites. The source further claimed that the SMN sites were used for the purpose of product advertisement and to maintain long-lasting customer relationships. However, the benefits are not limited as to communication purpose alone. It has also been used for the purpose of conducing marketing research activities and as a human resources recruitment tool. Additionally, the source claimed that $83 \%$ of enterprises considered social media as an important communication tool for their businesses.

A number of factors have contributed for the easy penetration of SMN. To begin with, the advantages gained by business organizations include low set-up cost, worldwide accessibility at any time, user adaptability, guidance, and help features. In addition to that, individuals enjoy reading the post purchase feedback and they can exchange various types of information from personal to work related. Figure 1 indicates the factors that contribute to purchase decision process.

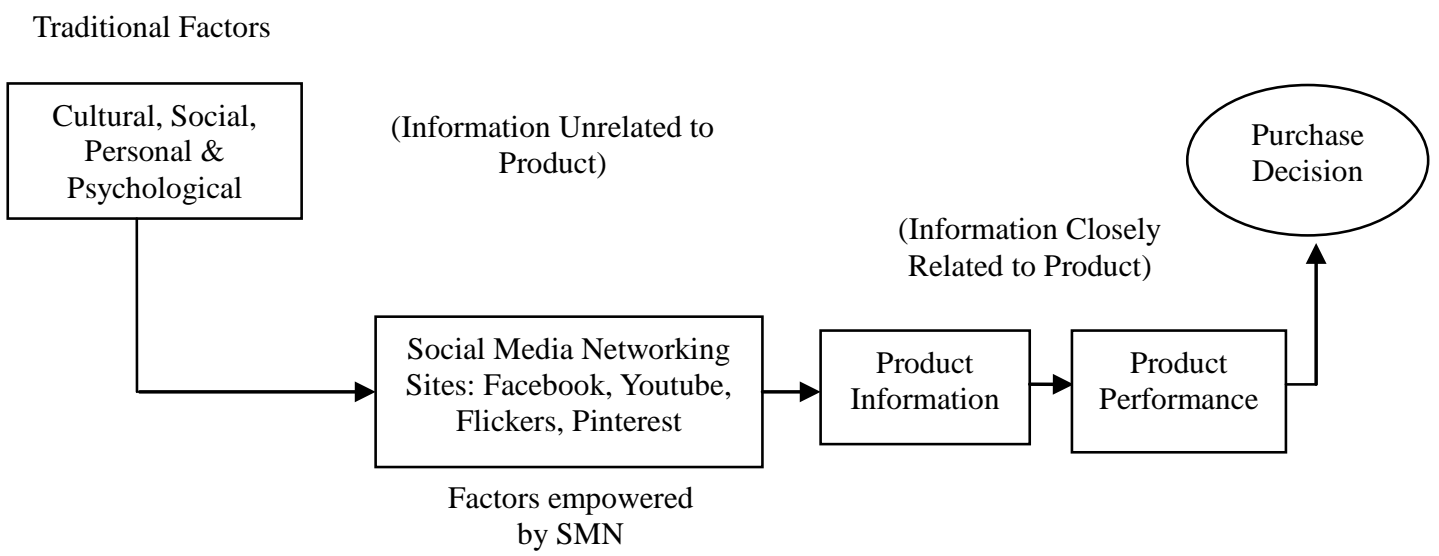

Figure 1. The factors that contribute to purchase decision process.

In the past, consumers were influenced by cultural, social, personal, and psychological factors in the decision making process. However, with the "birth" of user generated applications, www.facebook.com, www.twitter.com, consumer decision-making process is not only depending on those four traditional factors, but also getting empowered with SMN sites and feedbacks along with post-purchase reviews.

The factors that empowered by SMN provides an opportunity to consumers to review the post-purchase experience and comments which are considered to be powerful tips for any potential buyers. The multimedia sites such as YouTube ${ }^{\circledR}$ and MyVideo ${ }^{\circledR}$ enable enterprises to upload promotional clips while dissatisfied customers can capture scenes of collapsed service or damaged products and uploaded into the YouTube ${ }^{\circledR}$.

According to Mershon (2012), the SMN sites allow enterprises to engage in dialogue with customers. Consequently, it tends to boost the amount of sales for enterprises and lead to powerful brand awareness. The SMN sites uniqueness and various easily accessible channels will continuously embrace individuals to involve with the platform.

On the other hand, business organizations will continuously involve in preparing an effective strategic planning for the purpose of communicating with their precious customers through the SMN sites. It is an undeniable fact that SMN is becoming one of the prominent pathways of social communication in the 21st century. It can be easily subsumed that SMN turns out to be a vital attribute of the consumer purchase decision making process. It is noteworthy that the SMN sites are bringing enterprises and their target audiences much closer. 


\section{Increasing Dependency}

The SMN sites have attracted a huge number of individuals who engage themselves in the network and the number is building up tremendously. In line with that, enterprises are continuously making improved investments in the SMN sites in order to gain high return on marketing investment.

According to a survey carried out by Madden and Zickuhr (2011), among 2,277 respondents found that $65 \%$ of adults that have access to the Internet use social networking sites such as Facebook ${ }^{\circledR}$ and MySpace ${ }^{\circledR}$, and this number is getting increased when compared with $61 \%$ in the 2010 . The survey further revealed that $61 \%$ of adults who are under 30 years old use SMN sites at least once in a day. On the same lines, population that falls under the age category of 50-64 years now uses SMN sites actively. The percentage of usage increased from $20 \%$ in the year 2010 to $32 \%$ in the year 2011.

According to the Borell Associations (2011), the Small and Medium Enterprises (SME) intends to double their social media advertising budget in 2012. It is estimated to reach US\$2 billion in the United States alone. It is undeniable that enterprises around the world are taking part in the "race" in order to communicate and build long lasting customer relationship. Table 3 indicates category of online advertisement spending for the year 2011 and it also shows that social media ranks third in online advertising spending.

Table 3

Category of Online Advertisement Spending for the Year 2011

\begin{tabular}{lcc}
\hline Channel & Percentage & Ranking \\
\hline Audio & 3.10 & 11 \\
Banner-Run of Sites & 7.20 & 7 \\
Banner-Targeted Display & 8.50 & 5 \\
Business Directory & 12.00 & 4 \\
Email & 17.40 & 1 \\
Mobile & 5.50 & 8 \\
Search Engine & 15.10 & 2 \\
Social Media & 13.70 & 3 \\
Sponsorship & 5.10 & 9 \\
Streaming Videos & 8.10 & 6 \\
Others & 4.40 & 10 \\
\hline
\end{tabular}

The Facebook ${ }^{\circledR}$ sales in 2009 were US\$226 million and in the year 2010 and 2011 it increased to US\$606 million and one billion respectively. The $50 \%$ of the sales generated was through advertising and $20 \%$ from its Zynga game. On the other hand, Twitter ${ }^{\circledR}$ advertising revenue for 2012 is projected to reach US\$259 million and continue to reach US\$540 million in 2014.

The details in the Figure 2 was gathered through a survey that participated by 3,800 marketers (Stelzner, 2012). Many of the SMN sites users are engaged in a multiple SMN platforms. The feedback clearly indicates that Facebook ${ }^{\circledR}$ is leading all other SMN sites (see Figure 2).

According to Eric (2011), the overall market for virtual goods in the United States is headed towards US\$2.9 billion for 2012. That's up from US\$2.2 billion in 2011 and US\$1.6 billion in 2010. Virtual goods on Facebook ${ }^{\circledR}$ are continuing to comprise more than half of that, going from US\$835 million in 2010 to US\$1.2 billion in 2011 to US\$1.6 billion in 2012. The report estimates that mobile virtual goods (for games only) made US\$350 million in 2011, and will grow to US\$500 million in 2012.

Additionally, SMN sites can help boost business in the Middle East to a greatest level due to its 
extraordinary penetration in the region, reported by Khaleej Times (2012). The growth in this user generated sites continues to be astounding. According to Forrester Research (2010), one third of adults post at least once a week something to SMN sites such as Orkut ${ }^{\circledR}$, Facebook ${ }^{\circledR}$, and Twitter ${ }^{\circledR}$ and about $70 \%$ read blogs and tweets while a others watch videos on YouTube ${ }^{\circledR}$.

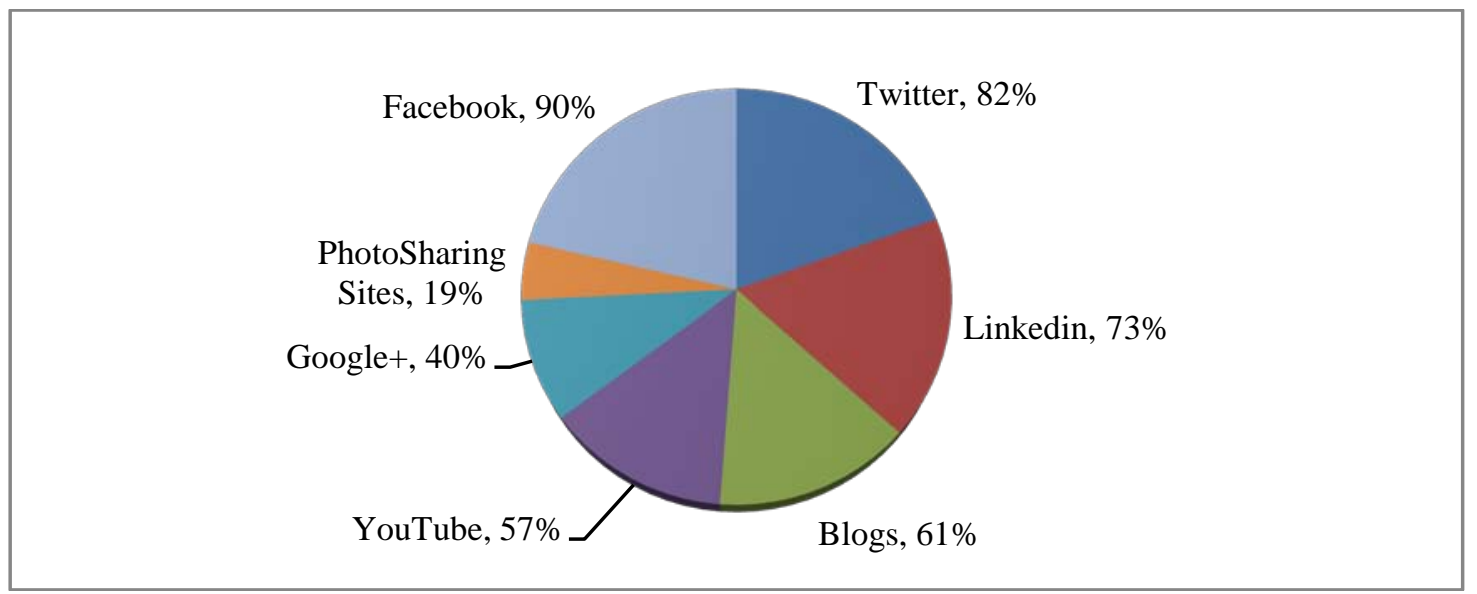

Figure 2. Commonly used SMN sites by enterprises for the year 2012.

A study indicates that $\operatorname{Netflix}^{\circledR}$, Toyota ${ }^{\circledR}$, Scottrade ${ }^{\circledR}, A T \& T \AA$, and Experian are some of the top five online advertisers. However, in the fast moving consumer goods industry some of the highly ranked names are Procter \& Gamble ${ }^{\circledR}$, Mars ${ }^{\circledR}$, General Mills, Kraft Foods etc. On the other hand, Google ${ }^{\circledR}$ dominated the Internet advertising, which has increased its share from 34.9\% in 2006 to 44.1\% in 2010 (Jacques, 2011). In addition to that, its early competitors Microsoft ${ }^{\circledR}, A O L \circledR$, and Yahoo ${ }^{\circledR}$ all have plunged to cope with race, their combined market share fell from 33.1\% in 2006 to 13.8\% in 2010. However, Facebook ${ }^{\circledR}$ increased its market share from just $13.5 \%$ in 2008 to $46.3 \%$ in 2010 and continues to capture $62 \%$ in 2012.

In the past, enterprises did not have such opportunities to talk to millions of customers that scattered around the globe so easily or even send out messages and get feedbacks in a second with relatively low cost. In this digital age, the Internet access becomes easily and widely available in many countries. Additionally, the traditional communication media are not equipped with features such as recommending products by independent persons or enable a click to "like" a brand. Therefore, the SMN sites have empowered enterprises with ways and means to harness and absorb opinion flow. According to a survey carried out by Businesswire.com (2010), it is claimed that more than 79\% of the 2,100 organizations surveyed said that they are currently using SMN channel in order to communicate with their consumers.

SMN sites are not only used for the purpose of social interaction but its usage is moving towards doing business transactions, from communicating business offerings to provide service after sales. The study governs that SMN sites can be used as an effective communication tool in order to reach out panoramic target audience.

\section{Conclusions}

The advent of internet-based SMN sites has ushered a new kind of reach out feasibility and relationship building process among enterprises and consumers. It is challenging the prevailing ideas about marketing and brand management while creating new platforms to communicate with customers and building a sustainable customer relationship. The rapid growth in the SMN sites and the increased involvement of consumers with 
them now triggered the evolution of new forms of marketing communication. Therefore, it becomes inevitable for the 21st century enterprises to involve themselves in the SMN process. In conclusion, it needs to be emphasized that the SMN is fast transforming the modern marketing communication channel.

\section{References}

Arno, C. (2012). Worldwide social media usage trends in 2012. Retrieved from http://searchenginewatch.com/article/2167518/Worldwide-Social-Media-Usage-Trends-in-2012

Barnes, N. D., \& Barnes, F. R. (2009). Equipping your organization for the Social Networking Game. Information Management Journal, 43(6), 28-33.

Booz \& Company and Buddy media. (2011). Booz \& Company and buddy media research highlights capabilities key to capturing value from social media. Retrieved from http://www.buddymedia.com/newsroom/2011/10/booz-company-and-buddy-media-research-highlights-capabilities-key-to-c apturing-value-from-social-media/

Borell Association. Com. (2011). 2011 online ad growth to outpace total ad spend growth. Retrieved from http://www.borrelassociates.com/component/content/article/45-general-report/195-borrell-associates-2011-ad-forecast-memo

Boyd, D. M., \& Ellison, N. B. (2007). Social network sites: Definition, history and scholarship. Journal of Computer-Mediated Communication, 13(1), 210-230.

Burson-Marsteller Asia Pacific. (2011). Asia pacific corporate social media study 2011. Retrieved from http://www.slideshare.net/bmasia/burson-marsteller-asiapacific-corporate-social-media-study-2011

Businesswire.com. (2010). Harvard business review analytics services releases study on the impact of social media. Retrieved from http:// businesswire.com/news/home/20101214006801/en/Harvard-Business-Review-Analytics-Services-Releases-Study

Cann, A., Dimitriou, K., \& Hooley, T. (2011). Social media: A guide for researchers. London: Research Information Network. Retrieved from http://www.rin.ac.uk/our-work/communicating-and-disseminating-research/social-media-guide-researchers

Eric, E. (2011). US virtual goods market to hit $\$ 2.9$ billion in 2012 . Retrieved from http://www.socialnetworkingwatch.com/2011/12/us-virtual-goods-market-to-hit-29-billion-in-2012.html

Forrester Research. (2010). Forrester forecast: Online retail sales will grow to $\$ 250$ billion by 2014. Retrieved from http:/techcrunch.com/2010/03/08/forrester-forecast-online-retail-sales-will-grow-to-250-billion-by-2014/

Hove, W. (2010). An anecdotal history of the people and communities that brought about the internet and the web. Retrieved from http://www.walthowe.com/navnet/history.html

Jacques, L. (2011). Quadrennial events to help ad market grow in 2012 despite economic troubles. Retrieved from http:/mediatel.co.uk/media-trend/new/2011/12/06/quadrennial-events-to-help-ad-market-grow-in-2012-despite-economic-tro uble

Kaplan, A. M., \& Haenlein, M. (2010). Users of the world unite! The challenge and opportunities of social media. Business Horizons, 53(1), 59-68.

Khaleej Times. (2012). Social media use can help boost business growth. Retrieved from http://www.khaleejtimes.com/kt-article-display-1.asp?section=uaebusiness\&xfile=data/uaebusiness/2012/june/uaebusiness_j une363.xml

Madden, M., \& Zickuhr, K. (2011). 65\% of online adults use social networking sites. Retrieved from http://pewinternet.org/Reports/2011/Social-Networking-Sites.aspx

Mangold, W. G., \& Faulds, D. J. (2009). Social media: The new hybrid element of the promotion mix. Business Horizons, 52(4), 357-365.

Melanson, D. (2011). UN: Worldwide internet users hit two billion, cellphone subscriptions top five billion. Retrieved from http://www.engadget.com/2011/01/28/un-worldwide-internet-users-hit-two-billion-cellphone-subscript/

Mershon, P. (2012). Five social media marketing trends: New research. Retrieved from http://www.socialmediaexaminer.com/5-social-media-marketing-trends-new-research-2/

Nair, G. T. R., \& Subramaniam, K. (2012). Transformation of traditional marketing communications into paradigms of social media networking. Asia Pacific Business Research Conference, 13-14 February 2012, Kuala Lumpur. World Research Papers. 
SOCIAL MEDIA NETWORK-A SEMINAL PARADIGM FOR INTERACTIVE MARKETING 203

New Media Trend Watch. (2011). Social networks and UGC. Retrieved from http://www.newmediatrendwatch.com/markets-by-country/17-usa/127-social-networks-and-ugc.

Rianovosti Internet User Report. (2012). Number of internet users worldwide tops 2 billion. Retrieved from http://en.rian.ru/world/20120120/170857236.html

Safko, L., \& Brake, D. K. (2009). The social media bible: Tactics, tools \& strategies for business success. New Jersey: John Wiley \& Sons.

Stelzner, M. (2012). How marketers are using social media to grow their business. Retrieved from http://www.socialmediaexaminer.com/SocialMediaMarketingIndustryReport2012.pdf?bcsi_scan_64A002839B46F548=0\&b csi_scan_filename=SocialMediaMarketingIndustryReport2012.pdf

Zenithoptimedia. Com. (2012). Quadrennial events to help ad market grow in 2012 despite economic trouble. Retrieved from http://zenithoptimedia.blogspot.com/2011/12/quadrennial-events-to-help-ad-market.html 